\title{
Islam on Campus: teaching Islamic Studies at Higher Education Institutions in the UK. Report of a conference held at the University of Edinburgh, 4 December 2006
}

\author{
Yasir Suleiman ${ }^{\mathrm{a} *}$ and Ayman Shihadeh ${ }^{\mathrm{b}}$ \\ ${ }^{\mathrm{a}}$ University of Cambridge, UK; ${ }^{\mathrm{b}}$ University of Edinburgh, UK
}

\section{Foreword}

The purpose of the 'Islam on Campus' conference was to consider the state of Islamic Studies in the UK. Its immediate context was the awareness that issues relating to the teaching of Islamic Studies were assuming greater importance, both on university campuses and in the funding and political arenas. The general interest in, and concern about, these issues has led to a number of previous events, including the Islam and Higher Education conference held in Birmingham between 20-30 January 2005, and a conference on The State of Arabic and Islamic Studies in Western Universities held at the School of Oriental and African Studies on 26 November 2006.

Direct impetus for the conference came from an article in the Times Higher Education Supplement entitled 'Islamic Teaching to be Scrutinised' (19 May 2006). It reported that the Higher Education Minister Bill Rammell was 'alarmed by "wrongheaded influences" on students', and had decided to launch a major review of the teaching of Islam on campus, in order to 'stamp out extremism'. The Higher Education Minister had come to the conclusion that 'the quality of teaching of Islam that takes place in our universities needs to be improved'. A copy of the article is shown in Appendix 4, reproduced with the kind permission of the Times Higher Education Supplement.

The Islam on Campus conference brought together academics involved in teaching and research in Islamic Studies at higher education institutions across the UK. The resulting discussion was wide ranging, considering issues such as the definition of

\footnotetext{
*Centre of Middle Eastern Studies, University of Cambridge, Sidgwick Avenue, Cambridge, CB3 90, UK. Email: ys310@cam.ac.uk
} 
Islamic Studies; the way that the political, institutional and funding contexts shaped academic and teaching practice; and the possibility of a link between Islamic Studies and extremism on UK campuses. The day was split into four sessions which considered the 'discipline' of Islamic Studies, its institutional settings, the political context and funding issues. Each session was structured around presentations by a selection of panellists, followed by a free discussion from the floor. The discussions were centred on but not limited to a number of questions which are in Appendix 2.

Because the conference was an exploratory event intended to provoke debate rather than reach conclusions, two disclaimers are necessary. First, a number of different views were expressed during the day and not everyone present agreed with all of them. The report seeks to represent this range of views, but neither we as its authors, nor any individual participant in the discussion, should be identified with any of the specific views reproduced here. For this reason, the discussion was held under 'Edinburgh Conversation Rules', whereby no attributions are made to named speakers. Second, the report may give the impression that discussion was streamlined with individuals falling into distinct or opposing camps. The reality was more nuanced, with any one participant sometimes expressing and exploring a range of different views. This report aims to strike a balance between reproducing the shifting and provisional nature of the discussion, and distilling it into a range of discrete positions.

The conference was sponsored by The Edinburgh Institute for the Study of the Arab World and Islam, and The Centre for the Advanced Study of the Arab World, which is a new Research and Funding Councils initiative between Edinburgh, Manchester and Durham Universities. The organisers would like to thank Katy Kalemkerian, Bill Roff, John Glendinning and Alan Whyte from the Language and Humanities Centre at the University of Edinburgh for their support before, during and after the conference. We would also like to thank all the participants for their contribution. In particular we would like to thank Paul Anderson for his assistance in compiling this report and revising parts of it on several occasions.

\section{Islam on Campus: an executive summary}

The University of Edinburgh has published a major report on the teaching of Islamic Studies in the UK. Recognising the growing political profile of Islamic Studies both on campus and in Whitehall, The Edinburgh Institute for the Study of the Arab World and Islam in collaboration with The Centre for the Advanced Study of the Arab World brought together leading academics in December to debate the politics of their discipline. The 'Islam on Campus' report summarises their findings.

Among the controversial topics discussed are the notion that a link might exist between Islamic Studies and extremism on campuses, and the assertion by government minister Bill Rammell that the teaching of Islam that takes place at our universities 'needs to be improved'. Both allegations are strongly denied by the professors and lecturers who took part in the conference. Many expressed dismay at the quality of public debate on extremism, with the media and even the Government too often influenced by poor research and self-proclaimed experts. 
The report describes a strong reaction against what was widely seen to be the increasing politicisation of Islamic Studies. Many present talked of increasing pressure from political interest groups, which had led in some cases to the intimidation of individual scholars and institutions. The scholars warned that an atmosphere of self-censorship fostered by the current political climate, and reinforced by recent government legislation, effectively put valuable research on certain movements and groups off-limits. Participants also discussed the recent government guidance on surveillance and extremism on campuses, and the dangers of academics taking public political stances, for example on the War on Iraq.

Many remarked on the changing context of the discipline. Some argued that traditionally there had been a close connection between Islamic Studies and diplomatic and security interests. But increasingly it was suggested that Islamic Studies could support the increasing numbers of Muslim students who were taking the subject to articulate the links between their different identities. Participants also debated whether Islamic Studies should focus purely on the classical literary and religious texts, or include sociological study of Muslims living in the modern world. Some suggested that there might be a gender imbalance among researchers and teachers in the field that played into false stereotypes of Islam as a 'male religion'.

The report also asks whether public funding for Islamic Studies is adequate. It discusses who else funds Islamic Studies in the UK, how this affects academic and teaching practice, and the increasing government role in deciding what it deems valuable topics for research.

\section{Session one: the discipline}

The discussion first considered the definition and scope of Islamic Studies. It was possible to distil two broad orientations from the debate, although not everyone aligned themselves in this way. On the one hand there was a case for seeing Islamic Studies as a discipline with its own methodology, core subjects and key texts. In this case, the field could be defined 'narrowly' as the study of classical religious texts and the religious sciences. On the other hand, it was suggested that the field could be fruitfully understood as the intersection of several disciplines. According to this understanding, the field could be defined more broadly as incorporating the ethnographic and sociological study of Muslim societies.

A number of points were made in support of a narrower definition of Islamic Studies:

- Study of the classical religio-intellectual disciplines and traditions should remain at the core of Islamic Studies, because they had been at the heart of the learned culture in Islamic civilisation and of the religion of Islam as such, and because many learned Muslims still regarded them as crucially important. The notion of Islamic Studies as the study of mainly pre-modern Arabic texts should therefore be defended. The core skill was expertise in the Arabic language. 
- Islamic Studies was a small field, especially in the UK. Broadening its scope might mean that quality suffered if Islamicists were expected to be 'jacks of all trades', providing courses in areas in which they were not properly qualified. The field faced continuing commercial pressure to broaden its scope to include, for example, a study of Islamic medicine and finance. But the most important imperative was to maintain the quality of the output. Research and teaching in areas that fell outside the narrow definition of Islamic Studies should therefore be pursued collaboratively with properly qualified external specialists.

- Faith-based education for Muslims about Islam, and the cross-disciplinary study of Islam drawing on the humanities and social sciences, both served useful purposes. However, Islamic Studies was distinct from both of these and should not be diluted. Properly pursued, it would enrich the other two fields. Anthropological and other social science interests were perfectly valid, but should not be termed Islamic Studies, any more than an anthropological approach to studying Christian societies would come under a field of 'Christianity Studies'.

- Agreeing a standard definition of the field would have its merits: at present, it was left to the staff of a particular faculty to define for themselves what counted as Islamic Studies.

Other points were made that tended to support a broader definition of the field:

- Universities tended to associate Islamic Studies with competence in primarily the Arabic language and a research focus on the intellectual, scholarly tradition of the Islamic religious sciences. An analysis of Islamic Studies post-holders at UK universities showed that the research interests of most lecturers were focused on the classical textual tradition rather than a sociological study of the contemporary Islamic world. This meant that post-holders were often unprepared for researching the puzzling evolutions of modern Islam. By contrast, the field of Jewish Studies had managed to incorporate the full scope of modern Judaism into its research and teaching agendas. In summary, there was a need to 'rebalance' the field of Islamic Studies by including sociological approaches and a study of the modern world.

- Teaching programmes should bridge the gap between the textual and ethnographic approaches to Islamic Studies, since students were often interested in what the traditional texts meant to the way people experienced and lived out their lives. Although textual study could encompass a variety of diverse traditions, confining the field to textual study alone risked giving the false impression of unified sets of practices, thus masking a more complex reality.

- Although some considered that there was ample textual research into a variety of Islamic traditions, there was a lingering perception that the study of Sufism (the mystical tradition in Islam) was not properly integrated into the field of Islamic Studies. It was suggested that there was a comparative lack of research into Sufism among Islamic Studies post-holders. This risked perpetuating the dichotomy between 'orthodox' Islam and 'heterodox' Sufism, and created a false image of completely 'orthodox' and uniform Islamic societies containing no diversity. It was 
therefore suggested that there was a need to reintegrate the study of Sufism into the field.

- It was important to resist the tendency to reify Islam, treating it as a single monolithic entity rather than a collection of diverse histories. This tendency was in part due to the public's (and students') desire to know about something called 'Islam'.

- Texts of the high classical tradition had been produced and were used by Muslims within a particular social context. Islam should be taught both as a textual tradition (with its own historical integrity), and as a social reality (which was dynamic and constantly changing). The two were linked: the textual tradition showed that Islam was, as well as a set of religious tenets, a way of approaching the practical economic and social challenges of life.

- Islamic Studies was not a discipline but lay rather at the intersection of several disciplines. In terms of methodology, researchers borrowed from a range of disciplines, including the social sciences. The lack of clear boundaries provided for an enriching interdisciplinary diversity.

- Islamic Studies should have a defined core of key areas and texts. Essentially, this should consist of the classical Islamic sciences. However, surrounding this core, other areas could be included, such as anthropology and the social sciences.

A related area of discussion concerned the context in which different definitions of Islamic Studies were produced and contested. The following points were made:

- It was a mistake to suggest that Islamic Studies could be easily defined. Academic fields did not have clear boundaries but were rather 'blurred genres'. It was also a mistake to suggest that the definition of a field of study could remain static. Disciplines were like tectonic plates, shifting because of changes in society and in the theory of knowledge.

- Islamic Studies was a contested area partly because Islam itself was contested, but also because the borders between subject areas were naturally blurred.

- Institutions themselves played a role in determining the scope of the field. Some private institutions had been founded with the explicit aim of 'rebalancing' the field of Islamic Studies by ensuring that it reflected the diverse Islamic heritage. They had been successful in a number of cases, as indicated by the growing number of reference works citing scholarship produced by these institutions.

- There was no agreed way to define either the method or the scope of Islamic Studies. The subject could be defined narrowly as study of the traditional core texts, or more broadly as the study of Muslims and Muslim societies. Islamic Studies was unique in being so broadly defined; Buddhist Studies, for example, did not include the study of Thai society.

- A distinction could be drawn between the traditional Quranic sciences, which gave rise to a static structure of key tenets, and Islamic Studies, which was a constantly shifting field. This distinction caused a dislocation for teachers of the subject, and was also responsible for its changing institutional setting.

- Despite its high political profile, there was a sense in which Islamic Studies was not yet a particularly self-reflective field. Given the changing context of Islamic 
Studies, there was a sense of urgency about the need to reflect critically on the field. In particular there was a need to critique the various methods and theories on which Islamic Studies was based, and to deconstruct the scholarly narratives about what Islam included and did not include. Much could be learnt from the social sciences in this regard. The debate about the future of Islamic Studies should advance not by constructing dichotomies such as confessional versus non-confessional, or textualist versus ethnographic, but by deconstructing the categories that the field took for granted, such as 'religion' and 'religious identity'.

- In considering definitions of Islamic Studies, it was important to remain alive to the sociology of knowledge. As soon as a 'core area' of Islamic Studies was defined, those trained in the core could form a profession and claim to be the conveyers of a particular kind of knowledge. But there was a debate about what constituted the core subjects of Islamic Studies. Some argued, for example, that Islamic economics was a central part of the subject. This could lead to an 'islamicisation' of knowledge, whereby those trained in Islamic Studies, but with little training in economics, could claim expertise in Islamic finance. At the same time, a broader definition of Islamic Studies raised the prospect that those with no knowledge of classical Arabic texts, such as international relations scholars, might play a central part in delivering the Islamic Studies curriculum, leading to a 'de-islamicisation' of the field.

- While classical Arabic texts formed the starting point for Islamic Studies, it was also essential to recognise how particular readings of these texts developed within specific traditions and social contexts. Because core texts developed out of a particular tradition, scholars should be aware of the kind of texts, and therefore traditions, on which the field of Islamic Studies was based.

A number of comments were made about the changing context in which Islamic Studies was pursued, and the impact of this on teaching methods and aims:

- The scope of Islamic Studies had traditionally been influenced by a number of factors, including state diplomatic and security interests. However, 'Islam' was no longer a phenomenon found simply in the Middle East and the Far East; it was also of personal relevance to many UK citizens. Students increasingly had expectations of courses that were not being met by the legacies of Orientalist knowledge, which tended to assume the superiority of a sceptical approach towards Islamic sources. In particular, an increasing number of Muslims were taking Islamic Studies, not to construct an apologia for Islam, but to inform their sense of Muslim identity, or rather to help articulate the links between the many facets of their identity. It was argued that teachers had a pedagogical and ethical duty to meet these needs, and to remain aware of the link between learning and identity formation.

- Some argued that the credibility of Islamic Studies in the UK was decreasing among some (principally but not exclusively Muslim) students. This was partly because some students sensed a provocative attitude in the way that some scholars presented debates about the authenticity of Islamic sources and even the existence of Prophet Muhammad. 
- On the other hand, it was important to avoid the type of marketisation that had occurred in the United States, where students were seen as customers and lecturers were forced to compete for their custom. Happily, there was less pressure in the UK to compete for students once they had enrolled on a degree course, so more emphasis could be put on education in the pure sense: inculcating habits of mind, learning to construct an argument and distinguishing between strong and weak evidence. In this sense, a degree in Islamic Studies should provide the same training as a degree in, say, Latin American Studies.

- Islamic Studies lecturers should introduce students to the experiential aspects of Islamic culture. Rather than focusing solely on texts and debates about the authenticity of historical sources, teaching should incorporate intrinsic oral and visual elements of the culture, such as Quranic recitation, novels, music and film. Because Islamic Studies was not a discipline but an intersection of disciplines, Islamicists should also invite the musician, ethnographer and architect, for example, to talk about aspects of Islam. The experiential was a vital part of grasping the nature of the subject and should not be denigrated as sub-intellectual.

- Others argued that the main role of undergraduate courses was to provide the linguistic and other training to enable future Islamicists to study the classical religious sciences. Since the level of training required to do this was high, and most new undergraduates came with no knowledge of Arabic, these courses needed to bridge a substantial gap in order to guarantee the future of the field.

- It was possible to combine an experiential approach with linguistic and scholarly rigour. Many universities stressed the importance of the undergraduate year spent in a Middle Eastern country because of the experiential benefits of being exposed to the Arabic language and the religious and cultural milieu. A number of university faculties teaching Islamic Studies also sought to instil both a scholarly objectivity and a respect for the sacredness of the subject.

- It was the nature of religion to stake a claim to certainty, but the nature of Islamic Studies, as a non-confessional discipline, was not to assess the truth of these claims. There was therefore a sense in which Islamic Studies missed the essence of religion.

Some points were also made about the recruitment of researchers:

- An analysis of Islamic Studies post-holders at UK universities revealed that the large majority of post-holders were male. This went strikingly against the trend in Western academia, particularly in the humanities. Some expressed the view that defining Islamic Studies in terms of classical Islamic disciplines might exclude women from applying or being successful in their applications for university lectureships. It was also suggested that the gender imbalance might play into the false stereotypes of Islam as being an essentially male religion. It was suggested that there was therefore a need to strive for a more equal gender balance among post-holders.

- Others argued that the overriding priority was to hire candidates regardless of gender who would publish high-quality work on the basis of primary sources and thus ensure that the understanding of Islamic history continued to develop. 
- Apart from the gender balance, it was noted that the field was otherwise diverse: lecturers came from a variety of ethnic backgrounds and occupied a mixture of faith-based and secular positions. Islamic Studies in the UK was neither entirely Orientalist nor entirely faith based, but showed a remarkable mixture of faithbased and secular approaches, and of Muslim and non-Muslim scholarship (which did not necessarily coincide with faith based versus secular). This was a good record which was however dented by an almost complete absence of Malay scholars in teaching Islam.

In conclusion, it was noted that while it would be hard to reach a universally agreed definition of Islamic Studies, there was merit in having the debate. The discussion had considered whether Islamic Studies was a single discipline or a wider subject area; whether it should be focused on the study of texts or the study of people; and if both, how the two types of study should interact. It had been suggested that Islamic Studies should have a core of key areas and texts, but that these should be contextualised; researchers should remain conscious of how particular readings of these texts developed within specific traditions and social contexts.

\section{Session two: institutional settings}

Discussion focused on the fragmented institutional context of Islamic Studies. It considered the effects and possible remedies of this fragmentation and the way that different institutes related to each other. The following points were made:

- Islamic Studies was institutionally fragmented, contained within a number of different settings from Religious Studies departments to Middle Eastern Studies departments. One result of this institutional fragmentation was that it was difficult to remain up to date with developments across the field. It might be useful to have an umbrella forum that brought the subject together, enabling scholars and researchers to engage critically with the whole field.

- A fragmented field was likely to suffer in terms of university prestige. An analysis of Islamic Studies post-holders at UK universities revealed that researchers tended to be relatively junior, which meant that Islamic Studies tended to be located at the fringes of university power and prestige. Some professors who were qualified Islamicists had a chair in Arabic Studies, not Islamic Studies. Indeed, there were only a handful of chairs and professorships in Islamic Studies, some of them externally funded, often by Gulf benefactors. This could be seen as a structural dilemma for the field, and was another reason to establish an umbrella organisation, such as a British Association for Islamic Studies, that could improve the field's recognition nationwide and increase funding by British sources.

- Others argued that the call for a new national umbrella body should be resisted. The British Society for Middle Eastern Studies (BRISMES) was already an excellent framework for discussing Islamic Studies in the UK. It was unclear whether scholars of Indonesian Islam, or indeed Islam in Britain, would be at home in an organisation concentrating on the Middle East. However, BRISMES had 
already produced two influential papers on the field of Islamic Studies in 2001 and 2003. Serious thought should therefore be given to establishing a working party, possibly within BRISMES, to take the current discussion forward. It would also be important to involve students in the discussion, asking them to reflect on their own experiences.

The question of fragmentation brought up the issue of how different departments and institutes related to each other: whether the relationship was one of competition, complementation, collaboration or a variety of these. The following points were made:

- Collaboration was an important part of many institutions' strategies. One institute for example had recently created a new Masters programme for teaching Islamic Studies in conjunction with an external institute of education.

- Relations between different institutions could also be characterised by healthy competition. Some recently established private institutes benchmarked themselves against their more established competitors in order to ensure that they produced scholars and scholarship that were on a par with the best in the field. In one case, a private institute had established an external board of international scholars to review its work every five years, thus applying the standards of its competitors to itself. Inevitably, having recruited and trained young scholars to high standards, such institutions lost many of them to rival institutions.

- The Government's approach could also encourage a certain sort of competitiveness. The institutional setting for Islamic Studies was typically either a Theology/ Religious Studies department, or a Middle Eastern Studies department. In a recent 'subject review' carried out at English universities by the Quality Assurance Agency, the former had been rated more highly overall than the latter. In particular, Religious Studies departments which taught Islam scored more highly on curriculum design than Middle Eastern Studies departments. But when it came to delivery of the curriculum, the picture was reversed: Middle Eastern Studies departments scored more highly. It was also noteworthy that Religious Studies departments that taught Islam performed better across the board in the subject review than Religious Studies departments that did not. These conclusions came with important caveats: for example, departments were marked according to how well they met their own objectives, so higher marks could signify less ambitious objectives rather than stronger performance. But overall, it was clear that awarding a department low marks, while potentially pleasing to a department's competitors, was likely to devalue the field of Islamic Studies as a whole in the eyes of the Government.

The discussion also considered the evolving institutional context of Islamic Studies. Picking up on the previous session's topic about whether or not Islamic Studies was a single discipline, participants debated whether Islamic Studies should be located in its own department. The following points were made:

- While the institutional context of Islamic Studies and the definition of the academic field evolved hand in hand, the core of the discipline was usually the 
study of the Arabic language. In the late nineteenth century, university faculties had often focused on Semitic languages and Near Eastern archaeology. In the 1970s, the emphasis had changed to Arabic studies and linguistics, and more recently to Arabic and Middle Eastern studies. So the institutional focus had developed from the (now largely defunct) areas of Semitic studies and Near Eastern archaeology to the (more modern) subjects of linguistics and history. But despite this evolving institutional context, study of the Arabic language remained at the core of the academic tradition.

- Some suggested that thought should be given to creating departments for Islamic Studies, although none currently existed in the UK. The numbers of undergraduate students and staff were growing. At present, several different academic areas, such as law, politics and international relations, all dealt in some way with Islamic Studies. Islamic Studies should be given an institutional home and recognised as a discipline in its own right.

- Others held that there could be no 'Department for Islamic Studies' because Islamic Studies was not a discipline, as it was not united by a common methodology. Scholars of Islamic history, for example, had to be measured against the standards of the discipline of history. The notion that Islamic Studies was a discipline might also lead to a 'compartmentalisation' of the subject, limiting rather than promoting the diversity of research. Finally, because the wider environment in which Islamic Studies was located was evolving quickly, there was a risk that an 'Islamic Studies Department' could become isolated, without long-term viability in the marketplace.

\section{Session three: politics and academic practice}

Practice discussion focused on the increasing politicisation of Islamic Studies, and the dangers this posed to academic freedom and intellectual rigour. Participants debated issues emerging from the Department for Education and Skills' (DfES) recent guidance Promoting Good Campus Relations (2006), in particular the possibility of a link between Islamic Studies and extremism. The following points were made:

- The academic practice of Islamic Studies was subject to increasing political interference. The situation in the USA was worse than in the UK, but in both cases it was deteriorating. The US Middle East Studies Association provided a stark warning for how the UK academic environment might suffer in the near future, with political pressure from three directions: donors, lobby groups and the Government.

- For example, perceiving a need to 'rebalance' the curriculum away from studies of the 'Third World', some US donors had funded alternative programmes focusing on Western civilisation. One university had established a course on 'American Ideals and Institutions', and another had opened a 'Centre for Freedom and Western Civilisation'. Donors were turning to the courts to enforce their will over the direction of research and teaching. 
- Lobby groups such as 'Campus Watch' in the USA also endangered intellectual freedom. Overt political pressure from these groups encouraged students to report on their teachers. This was reminiscent of McCarthyism and set a dangerous precedent. The attitude of many of the lobby groups in the USA was summed up in two direct quotes: 'the ivory tower exists at the sufferance of those who pay for it', and the 'only way to keep in line those who are tenured is to engage in robust public criticism'.

- Following the implementation of the Patriot Act, interference by the US Government in academic practice had also increased. The Department for Homeland Security, for example, had denied Professor Tariq Ramadan entrance to the United States, and Congress had been considering mechanisms for the formal oversight of Middle Eastern studies. The US Government used funding to alter the direction of research and teaching. Regrettably this could have the effect of turning colleague against colleague.

- It was necessary to understand the politicisation of academic practice within the wider political context. Three phases could be identified at the international level: the rapid changes in the Muslim world in the 1980s that followed from the Soviet invasion of Afghanistan and the Iranian revolution; the political changes in 1989 whereby the fear of Communism gave way to the fear of 'nothing'; and finally replacement in the 1990s of the Communist 'red menace' by the Muslim 'green menace'. The labelling of Muslims and creation of islamophobia needed to be understood in the context of the growth of US hegemony from 1989, an extreme neo-conservative attitude in parts of the United States political system and the terrorist attacks of September 2001 and July 2005.

Discussion then turned specifically to the situation in the UK. Particular attention was given to the guidance recently issued by the DfES (2006) entitled Promoting Good Campus Relations: Working with Staff and Students to Build Community Cohesion and Tackle Violent Extremism in the Name of Islam at Universities and Colleges. The following points were made:

- Historically, the UK had been admired across the world for its democracy and the independence of its educational traditions. Some saw the recent DfES guidance as a threat to these traditions. While no institution should tolerate criminality or allow it to be defended, it was vital to defend the UK's traditions of academic independence. The state's security services had a duty and a right to carry out their work professionally, but university lecturers should not be part of any system of surveillance.

- Some participants speculated that the government announcement that had heralded the recent DfES guidance may have built on four recommendations found in a pamphlet entitled When Students Turn to Terror by Anthony Glees and Chris Pope (2005). Although many viewed this as a controversial publication, such publications, it was argued, often shaped the public agenda, in particular because the mainstream media often relied on them and their authors for comment on extremism. The effects could be insidious, leading to the formation of groups such as Campus Watch. 
- The guidance from the DfES showed three types of confusion. First, it did not clearly separate the academic Islamic Studies curriculum from political Islamic activism. Second, it drew a distinction between (unacceptable) violent and (acceptable) non-violent action, but then blurred the distinction by suggesting that speech could be construed as violent action. Third, it proposed a distinction between groups (who could be targeted by the authorities) and individuals (whose freedom was to be protected), but it was unclear what this distinction meant in practice.

- It was important to distinguish between thought and action. Universities were often places where students engaged in alternativism, developing non-mainstream views of the world. This could be distinguished from radicalism, where young people felt strongly inspired by their learning environment. Both radicalism and alternativism could be distinguished from student activism.

- The political pressures on Islamic Studies posed three clear dangers to academic research: the erosion of civil liberties and free speech; self-censorship by academics; and the danger that, because particular kinds of research and fieldwork were deemed dangerous or suspect, academics would rely on secondary, official sources, thereby reinforcing official viewpoints.

- The danger of self-censorship was real. A number of researchers had already reported engaging in self-censorship because of the political climate. A political scientist, for example, might feel it was safer to shy away from presenting an organisation such as Hamas in its political context.

- Regrettably, recent legislation in the UK has narrowed the scope of research and education. Conducting research on a terrorist web site, or pursuing fieldwork alongside those whom the Government had deemed 'terrorist', could make the researcher liable to the provisions of the Terrorism Act. It was even possible that a lecture entitled 'William Wallace: Terrorist or Freedom Fighter?' could be construed as running foul of the law.

- Islamic civilisation should be studied 'warts and all'. Academics needed to analyse and understand a range of alternative discourses; and students needed to be exposed to all currents of thought, however much they might disagree with them.

- Another unfortunate result of the increasing politicisation of Islamic Studies was that a number of Islamic academic institutions and scholars had been unfairly maligned and intimidated. Islamic academic institutions and scholars were particularly vulnerable to unfounded criticism in the current political climate and could be easily marginalised. Sections of the UK media had often attacked Muslim commentators and scholars because of their background, rather than what they actually said. Some pro-Israeli lobby groups had also been particularly active in raising suspicions about individual Muslim scholars on this basis. This was regrettable because the alternative to faith-based teaching institutions was often extremist populist preachers who could exploit the fact that academics refrained from commenting on major issues such as the situation in Chechnya.

- Uninformed public debate could harm legitimate organisations. For example, although the term madrasa (traditional Islamic school) often appeared in the media 
with negative connotations as the place where students were 'radicalised', most madrasas were legitimate and responsible organisations. Regrettably, given their potentially central role, Muslim intellectuals were often 'caught in the middle', drawing accusations of Orientalist bias from Muslims, and of religious bias from non-Muslims. Non-Muslim scholars had also been maligned by groups such as 'Dhimmi Watch' as 'too sympathetic'.

A number of comments were made on the notion of a link between Islamic Studies and extremism on campuses:

- None of the researchers and lecturers present recognised any link between the teaching and curriculum of Islamic Studies and extremism at universities. The suggestion that such a link might exist betrayed a lack of understanding of the academic curriculum. University lecturers in general had no oversight of extracurricular societies.

- It was unclear whether the Government considered that there might be a link between the academic Islamic Studies curriculum and extremism on campuses. No evidence had been produced for such a link. Dr Attaullah Siddiqui of the Markfield Institute of Higher Education had agreed with the Government Minister for Higher Education the terms of reference for a study on the teaching of Islam at UK universities. Briefly, the study was to examine ways to ensure that Muslim students' spiritual and intellectual needs were met, and that they had access to material demonstrating how Islam could be practised within a contemporary pluralist society. ${ }^{1}$

- It was possible that in some isolated cases, institutions were validating degrees from foreign institutions without proper quality control, giving rise to concerns about irresponsible teaching of Islam. However, this was unlikely to be common; most academic institutions in the UK guarded their reputations closely and would not validate degrees irresponsibly.

- The teaching of Islamic Studies at UK universities in fact led to a better understanding of Islam, undermining the basis for extremism. It led Muslim and nonMuslim students, themselves from a variety of confessional and non-confessional backgrounds, to reflect critically on their own assumptions and practices. This was to be welcomed, since it provided the basis on which students could challenge their own communities.

- Islamic Studies had the potential to inform the thinking of Muslims across the UK and contribute to a reduction in extremism. In particular, high-quality, faith-based teaching, serving the Muslim community academically and intellectually, had a vital role to play at university level. This would benefit the Muslim community and by extension society at large.

- There were two ways to diffuse extremism: one was the Government's policy of regulation and control. The other was through the free exchange of ideas; combating one idea with another.

- At the same time, many participants agreed that the notion of academics as public intellectuals was problematic. Academics could be cast into the role of public 
intellectuals, having a public responsibility to criticise the Government and 'speak truth to power'. However, adopting any kind of public political stance or taking an advisory role to Government carried certain risks. Chief among these was the danger of being co-opted and lending credibility to particular political positions and government policies.

- There was naturally a danger that academic lectures and writings could reflect personal political attitudes. This was something that academics needed to be conscious of as individuals; it was not a suitable area for parliamentary legislation.

Finally, a number of participants made suggestions about steps for future action:

- Islamic Studies scholars might be well placed to participate in public debate based on a 'free exchange of ideas', although it might need a framework organisation to coordinate the debate. Any such forum would need proper recognition from the establishment. The forum could set the standard for one side of the debate in the same way as organisations such as Campus Watch set the standard for the other side of the debate.

- It was vital to engage with the mainstream media, especially given their role in inflaming the debate. One option would be to prepare a seminar with papers, and to invite a select group of journalists to explain to them the position of Islamic Studies scholars, and to confront them with some of the common misperceptions in the media. It was possible to change the discourse by engaging in the same territory as the media, but using terms such as jihad correctly. This could be done under the aegis of BRISMES, perhaps during a forthcoming plenary session.

- It was important to develop new constituencies of support, such as the Council of Higher Education Professors, while engaging in the debate about the future of Islamic Studies.

\section{Session four: funding}

It was noted that universities, research councils and external sources all played a role in funding Islamic Studies. Discussion focused on the system of research council funding, the differences between public and private funding, and the possibility of establishing a code of ethics for funding Islamic Studies. The following points were made about university and research council funding:

- Some universities left lecturers the freedom to decide what courses to provide. However, as funding was often allocated according to student numbers, there was some pressure to cater for students' interests. In particular, there was an increasing demand for courses about the basics of Islam.

- Research councils were an important source of funding for many institutions. Government was interfering increasingly in the allocation of the Arts and Humanities Research Council (AHRC) funding. While academics should ideally decide the allocation of research council funding, they rarely spoke with one voice. Since terrorism and religious fundamentalism had been identified by policy-makers as 
one of the six major challenges facing the world, research into these areas was likely to receive more resources. Universities encouraged researchers to work in these fields because of the kudos attached to receiving research council funding.

- The AHRC was changing to a system of block funding for a portion of its doctoral funding. This would affect the way Islamic Studies was resourced because there were no Islamic Studies departments in the UK. Handled well, the change could benefit Islamic Studies research, if institutes received a proportion of the funding. However, the general response to the change had not been favourable. Whereas in the past doctoral students had often been relatively free to pursue their own interests, the new funding mechanism brought a risk that research would simply 'follow the funding', thereby diminishing scholarly freedom.

- Islamic Studies consisted of a potentially confusing variety of subject areas that were difficult for public funders in the UK and at European level to navigate. The recent merging of the AHRC and the Economic and Social Research Council resources into a single domain focusing on 'religion and society' therefore made sense from the point of view of the research councils.

- Islamic Studies had a strong profile within the AHRC, partly due to its contentious and high-profile nature. The AHRC preferred to see it within the broader context of 'religion and society'. Within this rubric, academics needed to make the case for it to be directed towards Islamic Studies.

- It was important to ensure the continuation of proper public funding for Islamic Studies. Despite the current strong profile of Islamic Studies within the research councils, Islamic Studies historically had suffered from under-funding. Foreign donors were often sought because of the shortage of domestic funding. The European establishment should recognise Islamic Studies as deserving financial support, since this was a good way of strengthening the Muslim community.

The discussion also considered external sources and whether any meaningful distinctions could be drawn between public and private sources of funding. The following points were made:

- Public institutions often received both public and private funds. No general moral distinction could be drawn between accepting private and public sources of funding. Each case needed to be considered on its own merits. There was no objection to either type of funding if the source was 'clean', the funding unconditional and the research academically rigorous.

- While public funding was often useful and effective, it could come with handicaps. For example, the source often restricted how the fund was spent, and expected either a political or a commercial yield of some kind. Public funding could be used to serve a non-academic agenda, such as the recently proposed research council budget for 'countering radicalisation'.

- It was common also for implicit expectations to be attached to funding, whether from public or private sources. Implicit conditions could be attached more easily to funding given on a continuing basis than to one-off donations, because of the possibility of ceasing the funding if the implicit conditions were breached. 
- External private sources of funding often played a significant role in Islamic Studies, at both public and private institutions. Such sources of funding were often extremely 'loyal' and played a key role in supporting high-quality and intellectually rigorous research which would otherwise need public funds. In many cases the benefactor was based in an oil-rich Middle Eastern state. In some cases, institutes were funded from a single private source, and were therefore focused on a particular issue or driven by a particular vision.

- Private institutions could also receive both public and private funding. The use of government funding to support private Islamic institutes needed exploring. Islamic higher education institutes received very little public funding, although this option was often worth supporting.

- Private Islamic institutes were also sometimes set up by Muslim communities in order to provide a religious education for their children. This was usually done in a responsible way and led to positive results, although a case could be made for some kind of oversight mechanism to ensure that problems did not persist in the community.

Finally, some points were made about the possibility of establishing a funding code of ethics:

- It would be useful to establish a dialogue between different kinds of institutions using different kinds of funding mechanisms in order to establish best practice in each case.

- It could be useful to establish a dedicated code of ethics for funding, although a key question was who would enforce it. It might be useful to establish a body for this purpose that could ensure funding was academically sound, and also lobby the research councils so that funding was not directed solely at high-profile or 'glamorous' issues.

- Monitoring would be better carried out by academics than politicians. Thought should be given to establishing a 'Council for Islamic Studies Research' with charitable status which could both enforce a code of ethics and specialise in raising funds from which individual university researchers could apply for resources. Similar bodies existed for other disciplines. They provided for a more inclusive approach, enabling a variety of researchers, rather than a single institution, to benefit from the available funding. However, such a body might prevent donors from establishing a foundation or institute that associated their name with highquality research, thus depriving them of a key incentive.

- Many institutions already operated according to a code of ethics whereby donations were scrutinised to ensure that the source was 'clean' and the funding without conditions. In all cases it was vital that proper auditing procedures were followed.

- In some cases, particularly in the United States, funding was offered for a particular purpose or project which could be considered academically dubious. Scholars needed to consider all the circumstances and come to their own conclusions. 


\section{Conclusion}

The following points were made in conclusion:

Issues relating to the future of Islamic Studies were assuming greater importance, both on university campuses and in the funding and political arenas. It was important to take account of and respond to the variety of interests involved.

This introductory 'brainstorming' discussion had considered a range of issues related to the future of Islamic Studies. It had considered whether Islamic Studies should be considered a discipline or a subject area, whether its methods were essentially textual or ethnographic or both, and how these different elements should interact and relate. Thought had also been given to the way that the political, institutional and funding contexts shaped the practice of Islamic Studies. The potential impact of policy-making on academic freedom had been noted, as had the dangers of self-censorship and of the notion of the academic as a public intellectual.

In the view of those present, there was no link between the teaching of the Islamic Studies curriculum and extremism among students. The Islamic Studies curriculum was balanced, nuanced and designed with the long-term intellectual interests of the student at heart. While lecturers delivered the curriculum with integrity, they could not control how students used the knowledge that they received.

The discussion should continue in a more focused context, and suggestions would be invited as to how to take the various agendas forward. A meeting would be arranged in 2007 that could also include representatives from government departments.

\section{Note}

1. The full terms of reference for this study are included in Appendix 3.

\section{References}

Department for Education and Skills (2006) Promoting good campus relations: working with staff and students to build community cohesion and tackle violent extremism in the name of Islam at universities and colleges. Available online at: www.dfes.gov.uk/pns/DisplayPN.cgi?pn_id=2006_0170

Glees, A. \& Pope, C. (2005) When students turn to terror (London, The Social Affairs Unit). 


\section{Appendix 1. List of participants}

Professor Muhammad Abdel-Haleem (School of Oriental and African Studies, London)

Dr Andreas Christmann (University of Manchester)

Professor Anoush Ehteshami (University of Durham)

Dr Fareed El-Shayyal (Markfield Institute of Higher Education)

Professor Rob Gleave (University of Exeter)

Professor Robert Hoyland (University of St Andrews)

Dr Mawil Izzi Dien (University of Wales, Lampeter)

Dr Bustami Khir (University of Birmingham)

Dr Christopher Melchert (University of Oxford)

Dr Shuruq Naguib (University of Lancaster)

Professor Azim Nanji (Institute of Ismaili Studies, London)

Professor Ian Netton (University of Leeds)

Professor James Piscatori (University of Oxford)

Dr Ayman Shihadeh (University of Edinburgh, Organiser)

Dr Azzam Tamimi (Institute of Islamic Political Thought, London)

Other participants, all from the University of Edinburgh, included:

Paul Anderson

Dr Anthony Gorman

Professor Carole Hillenbrand

Dr Andrew Newman

Dr Kamran Rastegar

Professor William Roff

Professor Yasir Suleiman (Chair and Organiser)

Dr Richard Todd

Secretary of the meeting: Katy Kalemkerian

\section{Appendix 2. Questions discussed at the conference}

\section{SESSION I: THE DISCIPLINE}

1. What is 'Islamic Studies'? How do specialists in the field at UK institutions of higher education understand and define their discipline? For instance, what scope and objectives does Islamic Studies have? Does Islamic Studies carry any ideological baggage?

2. What approaches and methods are applied in Islamic Studies in the UK?

3. To what extent is Islamic Studies in the UK faith based? How does Islamic Studies compare in this respect with the study of other religious communities and traditions, including Christianity?

4. Who teaches Islamic Studies at UK institutions of higher education? What qualifications do they have? Can Muslims and non-Muslims teach Islamic Studies? 
5. To what extent can Islamic Studies be separated from Middle Eastern Studies and related disciplines?

\section{SESSION II: INSTITUTIONAL SETTINGS}

6. What are the different intellectual and institutional contexts in which Islamic Studies can be found in the UK (e.g. oriental studies, theology, religious studies, area studies, politics and political economy, gender studies and anthropology)? How do these affect the discipline?

7. What types of institutions offer Islamic Studies? How do the major universities and smaller private colleges compare in the courses they offer and in their enrolment and emphasis?

8. Is there a link between Islamic Studies and extremism at UK institutions of higher education?

\section{SESSION III: POLITICS AND ACADEMIC PRACTICE}

9. What lessons may be learnt from the American experience of dealing with Islamic Studies at universities? How does that experience compare with the situation in the UK?

10. Do allegations of radicalisation constitute an attack on civil liberties? Do they effectively erode academic freedoms, whether directly through the spectre of the Terrorism Act or indirectly through the engagement of academics in selfcensorship?

11. What is the role of academics specialising in Islamic Studies as public intellectuals and as politically engaged individuals?

\section{SESSION IV: FUNDING}

12. Who funds Islamic Studies at UK institutions of higher education? Do the sources of funding, whether public or private, exert any control over, or influence on, the field?

13. Are there any differences between publicly and privately funded institutions, e.g. in terms of methodology and vision?

14. Should there be a 'code of ethics' with regard to funding in Islamic Studies?

\section{Appendix 3. Terms of reference of a study entitled Teaching Islam at UK Institutions of Higher Education being undertaken by Dr Attaullah Siddiqui at the request of the UK Minister for Higher Education:}

What measures can be taken to improve the quality of information about Islam that is available to students and staff in universities in England; and in particular what can be done to ensure that students have access to material that helps them to understand how the teachings of Islam can be put into practice in pluralist contemporary society? 
What measures can be taken to improve the nature of spiritual advice and support that Muslim students can access in Universities in England?

What measures can be taken in order to identify the gaps, if any, between the needs and aspirations of Muslim students and the programmes of study presently available at Universities in England?

What measures can be taken to facilitate effective joint working by Government, local communities, the funding council and educational institutions to support these improvements?

\section{Appendix 4. Article from the Times Higher Education Supplement}

Islamic teaching to be scrutinised

Claire Sanders

Published: 19 May 2006

Minister alarmed by 'wrong-headed influences' on students launches review, reports Claire Sanders.

The Government has launched a major review of the teaching of Islam in colleges and universities in an effort to stamp out extremism on campuses.

Bill Rammell, the Higher Education Minister, who has just completed a ten-month tour of the sector, has asked Attaullah Siddiqui, director of the Markfield Institute of Higher Education, to conduct the review.

'Perhaps the most surprising thing I have come to conclude in recent months is that the quality of teaching of Islam that takes place in our universities needs to be improved,' Mr Rammell said at this week's launch of the review at South Bank University.

He said some students were subjected to 'wrong-headed influences... in particular, exposed to teachings that either explicitly condone terrorism or foster a climate of opinion that is at least sympathetic to terrorists' motivation.'

Mr Rammell said he was alarmed by some of the views expressed by Muslim students. 'I was really shocked to find a significant group of students in one institution who had bought the idea that 9/11 was planned and executed by the White House.'

Dr Siddiqui said this week that the review would examine what is taught on established courses as well as what is presented in campus Islamic societies. 'Although I am yet to receive my brief, I will be looking at gaps in current provision, and whether there could be a wider range of courses on offer,' he said. 'I will also be looking at the quality of religious teaching available from chaplaincies and Islamic societies.'

Mr Rammell wants to ensure that courses are not restricted to a narrow set of beliefs, that the nature of spiritual advice to students is improved and that more material is available to help explain Islam in the context of a multi-faith society.

Les Ebdon, vice-chancellor of Luton University and chair of the working party that produced a guide on fostering good campus relations for Universities UK, said: 'We have been very impressed that Bill Rammell has taken the time to visit universities and 
to talk to students. At Luton, students were clear that Muslims are, if anything, more alarmed about extremism than the Government has been in the past.'

He said he felt that extremism was easier to detect on campuses because of the open nature of universities. 'I do think young Muslims are more exposed to extremism in mosques than campuses.'

Amir Latif, media spokesman for the Federation of Student Islamic Societies, said: 'If this review is to look at what religious leaders say in Islamic societies on campuses then we would be concerned - that is a matter for Muslims themselves.'

Dr Siddiqui stressed that the review would offer guidance to universities and encompass a wide range of Muslim opinion.

The review will run alongside a study looking at whether British cultural and social history should become a compulsory part of schooling for 11 to 16-year-olds. 
Copyright of Journal of Beliefs \& Values: Studies in Religion \& Education is the property of Routledge and its content may not be copied or emailed to multiple sites or posted to a listserv without the copyright holder's express written permission. However, users may print, download, or email articles for individual use. 